\title{
Plant traits associated with resistance to Thrips tabaci in cabbage (Brassica oleracea var capitata)
}

\author{
Roeland E. Voorrips • Greet Steenhuis-Broers • \\ Marjolein Tiemens-Hulscher • \\ Edith T. Lammerts van Bueren
}

Received: 3 December 2007 / Accepted: 30 April 2008 / Published online: 30 May 2008

(C) The Author(s) 2008

\begin{abstract}
Thrips tabaci is a major problem in the cultivation of cabbage for storage, as this pest causes symptoms that necessitate the removal of affected leaves from the product. Between cabbage varieties large differences in susceptibility occur. This study aimed to identify plant traits associated with these differences, in field experiments with natural infestation in 2005 and 2006. One factor affecting the amount of thrips damage was the timing of the development of the head. In an experiment with different planting dates especially the early maturing, more susceptible varieties were shown to benefit from later planting. In comparisons of multiple varieties in both years, regression studies showed that more advanced plant development in August and early September increased thrips damage at the final harvest. However, no single plant trait explained more than $25 \%$ (2005, Brix) or $48 \%$ (2006, compactness) of the variation in thrips damage. Optimal regression models, explaining up to $75 \%$ of the variation in thrips damage included Brix and leaf surface wax late in the season, as well as
\end{abstract}

R. E. Voorrips $(\bowtie) \cdot$ G. Steenhuis-Broers Plant Research International, P.O. Box 16, 6700 AA Wageningen, The Netherlands e-mail: roeland.voorrips@wur.nl

M. Tiemens-Hulscher - E. T. Lammerts van Bueren Louis Bolk Institute, Hoofdstraat 24, 3972 LA Driebergen, The Netherlands an indicator of plant development earlier in the season, and in 2005 also leaf thickness. The possible role of these plant traits in relation to thrips is discussed.

Keywords Thrips tabaci $\cdot$ Brassica oleracea var capitata $\cdot$ Resistance $\cdot$ Brix $\cdot$ Wax $\cdot$ Maturity

\section{Introduction}

Cabbage (Brassica oleracea var capitata) is an important field crop in the Netherlands, cultivated by conventional as well as organic growers. Cabbage cultivated for storage is usually harvested around mid-October. This type of cabbage crop may be severely damaged by thrips (Thrips tabaci). Interviewed organic growers in the Netherlands indicate that thrips is the most important constraint in cabbage production. As thrips can feed and survive on onion and on leek which is increasingly grown as a year-round crop, it becomes an increasing problem. The damage caused by thrips is due to the symptoms that develop after feeding, which are small callus-like growths (intumescences) that will turn brownish after some time. These symptoms force growers to remove the outer leaf layers before marketing, leading to increased labor costs and yield losses.

Among red and white cabbage varieties, large differences have been reported in the amount of thrips damage (Shelton et al. 1983; Stoner and 
Shelton 1988; Van de Steene et al. 2003) and in the numbers of thrips observed on the plants (Stoner and Shelton 1986; Van de Steene et al. 2003). There appears to be no clear relation between the size of the thrips population on the frame leaves and in the cabbage head.

The ranking of varieties with respect to thrips damage is not affected by the observed plant stage or ripeness, as long as all plants are observed at the same stage. In experimental fields with multiple varieties, i.e. in a choice situation part of the difference in thrips population development can be attributed to differences in thrips preference. For another part, differences in thrips growth and reproduction are responsible (Stoner and Shelton 1988).

The genetic background of tolerance or resistance to thrips is not clear. In two quantitative studies, not based on genetic markers, Stoner and Shelton (1986) and Stoner et al. (1989) concluded that inheritance of thrips resistance is quantitative and more or less recessive. Their 1989 study also uncovered evidence for epistatic interactions. From this they concluded that performance of parental lines is not sufficient to predict the level of F1 hybrid resistance or tolerance.

Breeding for resistance or tolerance to thrips is difficult. One of the problems is the largely unknown, but probably oligo- or polygenic inheritance of this trait. Another difficulty is the large variability between years and locations in the severity and timing of thrips infestation. Also within genotypes in the same experiment, large plant to plant variations can occur in damage or thrips population size. Furthermore, it is not easy to have all the accessions in a comparable developmental stage throughout the evaluation period, which is a requirement for reliable comparisons. For this reason indirect selection would be helpful. One possibility is to identify plant traits that are associated with the level of thrips damage. That was the main aim of the research described in this paper. Also knowledge of agronomically undesirable traits associated with trips resistance would be important, as these must be avoided while selecting for resistance. Another aim of our research was the identification of open-pollinated varieties with high and low levels of thrips resistance that may be used as parents of crosses aimed at the study of the inheritance of thrips resistance.

\section{Materials and methods}

Field experiments

In 2005 and 2006, field experiments were carried out at two locations in the Netherlands: Wageningen (clay soil, conventionally managed) and Zwaagdijk (clay soil, organically managed). Plants were transplanted to peat blocks one week after sowing, around May 1 in both years, and transplanted to the field on May 26-27, 2005 and May 30-31, 2006. In the 2005 experiments, four of the accessions (cvs Bartolo, Slawdena, Rivera and Galaxy) were sown again three weeks later and transplanted to the field on June 1617. Planting distance in the field was $50 \times 50 \mathrm{~cm}$. At both locations, the experimental fields were divided into three blocks, with one plot per accession per block; in 2005 the fields of the two planting dates were adjacent to each other. Each field was surrounded by a double row of cv Rivera. Each plot consisted of $5 \times 9$ plants. At four harvest dates three adjacent plants were harvested from each plot; all plants remained surrounded by other plants of the same accession until they were harvested. The dates of harvest 1-4 in 2005 were 10-11 August, 30-31 August, 26-27 September and 18-19 October; for 2006 harvests 1-4 were at 15-16 August, 5-6 September, 25-26 September and 2 October.

Harvested plants were scored for a number of morphological and anatomical traits, chosen in part based on suggestions of organic farmers. Observations included developmental stage (according to the scale of De Moel et al. (1996); the relevant part of the scale was from $3.0=$ onset of head formation, through $4.0=$ optimal harvest stage to $4.9=$ overripe and cracked), circumference of the head $(\mathrm{cm})$, openness around the stem (visual scores, $0=$ fully closed, 3 = very open) when observed from below. The outermost leaf of the head was used to assess leaf thickness $(\mathrm{mm})$ and wax layer (visual scoring after rubbing part of the leaf: $1=$ no visible wax, $9=$ thick wax layer). After halving the heads longitudinally they were scored for compactness (visual score: $0=$ top of leaves not yet curving inwards, $9=$ head completely packed, no empty spaces remaining). One half of each head was peeled and assessed for thrips damage $(0=$ no damage, $9=$ the 8 outer head leaves $100 \%$ affected) and the number of adult thrips. The other halves of the three plants per plot were pooled and 
Table 1 Plant material

\begin{tabular}{lllll}
\hline Accession & Donor & Type $^{\mathrm{a}}$ & 2005 & 2006 \\
\hline Bartolo & Bejo & F1 & x & x \\
Galaxy & Seminis & F1 & x & x \\
Rivera & Bejo & F1 & x & x \\
Slawdena & Bejo & F1 & x & x \\
Bewama & CGN & OP & x & x \\
Langendijker Bewaar (LB) $)$ & CGN & OP & x & x \\
Uniflor & Syngenta & F1 & x & \\
Amager Hoj-Gron Grami & CGN & OP & x & \\
Deense Kortpoot & CGN & OP & x & \\
Selectie Smit & CGN & OP & x & \\
Bewama $\times$ LB & PRI & Exp & & x \\
LB $\times$ Bewama & PRI & Exp & & x \\
Agressor & Syngenta & F1 & & x \\
Ancoma & Rijk Zwaan & F1 & & x \\
Counter & Bejo & F1 & x \\
Selma & Rijk Zwaan & F1 & x \\
WCA 352 & Syngenta & F1 & x \\
\hline
\end{tabular}

${ }^{a}$ Type: $\mathrm{F} 1$ = F1 hybrid variety, $\mathrm{OP}=$ Open-Pollinated variety, Exp $=$ Experimental material

b $\mathrm{CGN}=$ Centre for Genetic Resources, The Netherlands

c PRI = Plant Research International, The Netherlands

ground, the sap was filtered through $53 \mu \mathrm{m}$ mesh cloth and assessed for Brix value using an Atago N20 hand-held refractometer.

\section{Plant material}

The plant material consisted of medium to late white cabbage varieties, including both $\mathrm{F} 1$ hybrids and classical open-pollinated varieties (Table 1). In 2006, the reciprocal F1's of a cross between two open-pollinated varieties (Bewama and Langendijker Bewaar) were also included in the experiments. Three of the F1 hybrids were chosen as standards, as it was known that they were highly susceptible (Bartolo and Slawdena) or resistant (Galaxy) to thrips damage.

\section{Data analysis}

Data were analyzed per harvest date using ANOVA, with Location * Accession as treatment and Location/ Block as block structure (Genstat 9, Payne et al. 2006). Where necessary, data were transformed to obtain more uniform residual variances: for number of thrips adults per plant and for thrips damage the data were transformed to $\log (x+1)$, and the scores for developmental stage were transformed to $\log (\mathrm{x})$. Correlations between traits were based on plot means over both locations per harvest. Optimal multiple regression models for thrips damage were derived by performing all-subsets regression (Miller 2002) as implemented in the R 2.6.0 (R Development Core Team 2007) package 'leaps' and selecting those models that had Mallows' Cp values (a statistic that rewards accurate prediction but penalizes over-fitting; Mallows 1973) between 1 and 2 times the number of explanatory variables.

\section{Results \\ Effect of planting date}

In 2005, four F1 hybrid varieties (Bartolo, Slawdena, Rivera and Galaxy) were sown and planted at two dates with an interval of three weeks. Plants of both planting dates were harvested and evaluated at the same four harvest dates, which allowed a comparison of the same varieties, grown under the same environmental conditions at different developmental stages. Cabbages in the field in Zwaagdijk developed slightly slower than in Wageningen for all varieties and both planting dates. Plants of Rivera and Galaxy of both planting dates were significantly $(P<0.05)$ less far developed than Bartolo and Slawdena in the first two harvests; in the third harvest the difference was only significant for the late planting in Wageningen, and in the fourth harvest no significant differences were observed between the varieties.

Serious thrips damage was observed in harvests 3 and 4 (Table 2). The general pattern indicates that Slawdena and Bartolo are highly affected, Rivera is less affected, and Galaxy shows the lowest level of damage. In Zwaagdijk the two earliest varieties (Bartolo and Slawdena) and one of the late varieties (Rivera) show a lower thrips damage when planted later, whereas for Galaxy, the other late variety, planting date does not have an effect.

The number of thrips per plant was more variable, such that not many significant contrasts could be demonstrated between the varieties (results not shown). Nevertheless, the number of thrips was significantly smaller in the late-planted than in the early-planted plots of cv Rivera (harvest 3 and 4) and of cv Bartolo 
Table 2 Effect of planting date on Trips damage

\begin{tabular}{|c|c|c|c|c|c|}
\hline \multirow[t]{3}{*}{ Variety } & \multirow{3}{*}{$\begin{array}{l}\text { Location } \\
\text { Harvested: }{ }^{1} \\
\text { Planted: }{ }^{1}\end{array}$} & \multirow{2}{*}{\multicolumn{2}{|c|}{ September 26}} & \multirow{2}{*}{\multicolumn{2}{|c|}{ October 19}} \\
\hline & & & & & \\
\hline & & May 26 & June 16 & May 26 & June 16 \\
\hline Slawdena & \multirow[t]{4}{*}{ Wageningen } & $5.76 b^{2,3}$ & $4.38 \mathrm{ab}$ & $3.71 \mathrm{c}$ & $3.45 \mathrm{bc}$ \\
\hline Bartolo & & $2.81 \mathrm{a}$ & $4.35 \mathrm{ab}$ & $3.76 \mathrm{c}$ & $4.02 \mathrm{c}$ \\
\hline Rivera & & $2.75 \mathrm{a}$ & $3.35 \mathrm{a}$ & $3.45 \mathrm{bc}$ & $2.28 \mathrm{ab}$ \\
\hline Galaxy & & $2.89 \mathrm{a}$ & $3.09 \mathrm{a}$ & $2.00 \mathrm{a}$ & $2.09 \mathrm{a}$ \\
\hline Slawdena & \multirow[t]{4}{*}{ Zwaagdijk } & $4.65 \mathrm{~d}$ & $2.13 \mathrm{bc}$ & $4.45 \mathrm{bc}$ & $3.07 \mathrm{~b}$ \\
\hline Bartolo & & $6.47 \mathrm{~d}$ & $2.70 \mathrm{c}$ & $5.39 \mathrm{c}$ & $3.78 \mathrm{bc}$ \\
\hline Rivera & & $4.80 \mathrm{~d}$ & $1.39 \mathrm{ab}$ & $3.46 \mathrm{~b}$ & $1.50 \mathrm{a}$ \\
\hline Galaxy & & $1.00 \mathrm{a}$ & $1.62 \mathrm{abc}$ & $1.29 \mathrm{a}$ & $1.29 \mathrm{a}$ \\
\hline
\end{tabular}

${ }^{1}$ Harvest and Planting dates are in 2005

${ }^{2}$ Numbers are ANOVA means of Thrips damage scores, backtransformed to original scale $(0=$ no damage; $9=$ all leaves $100 \%$ affected)

${ }^{3}$ Means followed by the same letter, within the same Location and Harvest date, are not significantly different at $P=0.05$

and Slawdena (harvest 4 only). Cv Galaxy contained almost no thrips at any of the locations and harvests.

Genotypic differences for thrips damage and number of thrips

The thrips damage and number of adult thrips per plant were calculated per harvest for all accessions, excluding the material of the second planting date in 2005 (Table 3). Large differences between genotypes were observed for both traits. For the six accessions tested in both years the results of 2005 and 2006 were comparable. The numbers of thrips per plant were more variable than the damage scores, which resulted in a better discrimination of accessions for damage score than for thrips numbers. However, for both traits Galaxy, Langendijker Bewaar and Amager Hoj-Gron Grami stood out as the most resistant or least damaged accessions, while Bartolo, Bewama and Slawdena were the most susceptible. The differences between these two groups were consistent over all harvest dates, although not at all dates the differences were significant.

In harvest 4, the reciprocal F1's between Bewama and Langendijker Bewaar scored intermediate between the parents: both for number of thrips and for thrips damage their scores differed significantly from both parents (Table 3). In the earlier harvests the same trend appears but due to the smaller variation between genotypes the differences are mostly not significant.
Relations between plant traits and thrips damage

For both years plot means were calculated per harvest for all measured traits (where necessary after transformation of the data, see section 'Materials and methods'), and correlated with thrips damage measured in the final harvest. Individual traits measured at any harvest showed only limited correlations with thrips damage, with maximum $\mathrm{R}^{2}=0.25$ (2005, Brix in third harvest, $P<0.001)$ and 0.48 (2006, Compactness in second harvest, $P<0.001)$. We used all-subsets regression and selected models as described in section 'Materials and methods' in order to obtain improved predictors for thrips damage while avoiding over-fitting. The selected models with the highest proportion of variance explained were:

$$
\begin{aligned}
& \text { 2005: Damage } 4=-1.23+0.23 * \text { Brix } 4+ \\
& 0.019 * \text { Circ } 2-0.22 * \operatorname{Wax} 3+0.66 * \text { Thick } 4 \\
& \left(\mathrm{R}^{2}=0.75\right) \\
& \text { 2006: Damage } 4=-2.73+0.34 * \text { Brix } 3 \\
& \quad+1.8 * \text { Stage } 2-0.16 * \text { Wax } 4\left(\mathrm{R}^{2}=0.74\right)
\end{aligned}
$$

where Damage is thrips damage, Circ is circumference, Wax is the amount of leaf surface wax, Thick is leaf thickness, Stage is developmental stage, and the figure (1-4) indicates the harvest.

However, in both years several other models with the same number of parameters explained almost the same proportion of the variance as the two optimal models specified above. In both years these models included Brix and leaf surface wax in the third or fourth harvest and a trait indicative of development of the head (i.e. the score of developmental stage, firmness or circumference) in the first or second harvest. In 2005 but not in 2006 leaf thickness in harvest 4 occurred in all models.

Comparing these results with the individual correlations of different traits with the damage at the final harvest a similar picture is obtained. Correlations of the traits indicative of development with final damage are lower in the last two than in the first two harvests, while correlations with leaf surface wax are higher in the last two harvests. For Brix the trend of the correlation with damage over the harvests is less clear. For all these traits at all harvests, the individual correlations with final damage have the same sign as in the two formula's above. This is not the case for leaf thickness: correlations of thrips damage and leaf thickness over different harvests vary much and may also change sign. 
Table 3 Thrips population and thrips damage in cabbage accessions in four harvests over 2 years

\begin{tabular}{|c|c|c|c|c|c|c|c|c|c|}
\hline \multirow[t]{2}{*}{ Accession } & \multirow[b]{2}{*}{ Harvest } & \multicolumn{4}{|l|}{2005} & \multicolumn{4}{|l|}{2006} \\
\hline & & 1 & 2 & 3 & 4 & 1 & 2 & 3 & 4 \\
\hline \multicolumn{10}{|l|}{ Thrips adults per plant } \\
\hline Bartolo & & $0.3 \mathrm{abc}$ & $0.4 \mathrm{ab}$ & $2.9 \mathrm{c}$ & $11.4 \mathrm{~d}$ & 3.7 ef & $0.4 \mathrm{ab}$ & $1.8 \mathrm{~d}$ & $13.6 \mathrm{f}$ \\
\hline Bewama & & $0.6 \mathrm{bc}$ & $0.9 \mathrm{~b}$ & $2.2 \mathrm{bc}$ & $9.9 \mathrm{~cd}$ & $3.4 \mathrm{def}$ & $0.4 \mathrm{ab}$ & $1.5 \mathrm{~cd}$ & 10.7 ef \\
\hline Galaxy & & $0.1 \mathrm{a}$ & $0.1 \mathrm{ab}$ & $0.4 \mathrm{a}$ & $0.4 \mathrm{a}$ & $1.3 \mathrm{ab}$ & $0.2 \mathrm{ab}$ & 0.7 abcd & $2.9 \mathrm{~b}$ \\
\hline Langendijker Bewaar (LB) & & $0.1 \mathrm{a}$ & $0.0 \mathrm{a}$ & $0.3 \mathrm{a}$ & $0.7 \mathrm{a}$ & $0.8 \mathrm{a}$ & $0.0 \mathrm{a}$ & $0.3 \mathrm{ab}$ & $0.3 \mathrm{a}$ \\
\hline Rivera & & $0.0 \mathrm{a}$ & $0.3 \mathrm{ab}$ & $3.0 \mathrm{c}$ & $6.9 \mathrm{~cd}$ & $1.4 \mathrm{abc}$ & $0.1 \mathrm{ab}$ & $1.0 \mathrm{abcd}$ & $15.5 \mathrm{f}$ \\
\hline Slawdena & & $0.7 \mathrm{c}$ & $0.7 \mathrm{ab}$ & $2.2 \mathrm{bc}$ & $8.0 \mathrm{~cd}$ & 3.9 ef & $0.3 \mathrm{ab}$ & $0.7 \mathrm{abcd}$ & $5.4 \mathrm{~cd}$ \\
\hline Amager Hoj-Gron Grami & & $0.0 \mathrm{a}$ & $0.3 \mathrm{ab}$ & $0.7 \mathrm{ab}$ & $0.4 \mathrm{a}$ & & & & \\
\hline Deense Kortpoot & & $0.6 \mathrm{bc}$ & $0.0 \mathrm{a}$ & $0.7 \mathrm{ab}$ & $1.3 \mathrm{ab}$ & & & & \\
\hline Selectie Smit & & $0.7 \mathrm{c}$ & $0.6 \mathrm{ab}$ & $0.3 \mathrm{a}$ & $3.6 \mathrm{bc}$ & & & & \\
\hline Uniflor & & $0.2 \mathrm{ab}$ & $0.4 \mathrm{ab}$ & $1.0 \mathrm{abc}$ & $0.7 \mathrm{a}$ & & & & \\
\hline Agressor & & & & & & $1.4 \mathrm{ab}$ & $0.6 \mathrm{~b}$ & $0.7 \mathrm{abcd}$ & $3.0 \mathrm{~b}$ \\
\hline Ancoma & & & & & & $1.7 \mathrm{abcd}$ & $0.2 \mathrm{ab}$ & $0.2 \mathrm{a}$ & $4.2 \mathrm{bcd}$ \\
\hline Counter & & & & & & $3.1 \mathrm{cde}$ & $0.5 \mathrm{ab}$ & 0.7 abcd & $6.6 \mathrm{de}$ \\
\hline Selma & & & & & & $1.2 \mathrm{a}$ & $0.0 \mathrm{ab}$ & $1.2 \mathrm{bcd}$ & $4.9 \mathrm{bcd}$ \\
\hline WCA 352 & & & & & & $6.4 \mathrm{f}$ & $0.3 \mathrm{ab}$ & $0.3 \mathrm{ab}$ & $4.9 \mathrm{bcd}$ \\
\hline F1 $($ Bewama $\times$ LB $)$ & & & & & & $2.8 \mathrm{bcde}$ & $0.0 \mathrm{a}$ & $1.4 \mathrm{~cd}$ & $3.8 \mathrm{bc}$ \\
\hline F1 $($ LB $\times$ Bewama $)$ & & & & & & 1.9 abcde & $0.0 \mathrm{ab}$ & $0.5 \mathrm{abc}$ & $3.0 \mathrm{~b}$ \\
\hline \multicolumn{10}{|l|}{ Thrips damage } \\
\hline Bartolo & & $0.2 \mathrm{ab}$ & $1.8 \mathrm{bcde}$ & $4.3 \mathrm{~d}$ & $4.5 \mathrm{ef}$ & $0.9 \mathrm{de}$ & $3.9 \mathrm{fg}$ & $4.0 \mathrm{~d}$ & $6.8 \mathrm{~g}$ \\
\hline Bewama & & $0.6 \mathrm{c}$ & $2.1 \mathrm{de}$ & $4.6 \mathrm{~d}$ & $5.0 \mathrm{f}$ & 0.9 cde & $3.2 \mathrm{efg}$ & $3.3 \mathrm{~d}$ & $5.9 \mathrm{fg}$ \\
\hline Galaxy & & $0.0 \mathrm{a}$ & $1.0 \mathrm{a}$ & $1.8 \mathrm{a}$ & $1.6 \mathrm{a}$ & $0.0 \mathrm{a}$ & $2.1 \mathrm{bcde}$ & $1.3 \mathrm{ab}$ & $2.0 \mathrm{~b}$ \\
\hline Langendijker Bewaar (LB) & & $0.0 \mathrm{a}$ & $1.0 \mathrm{a}$ & $1.9 \mathrm{ab}$ & $2.5 \mathrm{bc}$ & $0.2 \mathrm{ab}$ & $0.3 \mathrm{a}$ & $0.8 \mathrm{a}$ & $0.3 \mathrm{a}$ \\
\hline Rivera & & $0.0 \mathrm{a}$ & $1.2 \mathrm{ab}$ & $3.7 \mathrm{~cd}$ & $3.5 \mathrm{cde}$ & $0.2 \mathrm{ab}$ & $1.5 \mathrm{~b}$ & $2.7 \mathrm{~cd}$ & $4.6 \mathrm{def}$ \\
\hline Slawdena & & $0.1 \mathrm{ab}$ & $2.1 \mathrm{cde}$ & $5.2 \mathrm{~d}$ & $4.1 \mathrm{def}$ & $1.1 \mathrm{de}$ & $4.2 \mathrm{~g}$ & $3.1 \mathrm{~cd}$ & 4.9 efg \\
\hline Amager Hoj-Gron Grami & & $0.0 \mathrm{a}$ & $1.6 \mathrm{abcd}$ & $2.1 \mathrm{ab}$ & $2.3 \mathrm{ab}$ & & & & \\
\hline Deense Kortpoot & & $0.3 \mathrm{bc}$ & $2.6 \mathrm{e}$ & $3.7 \mathrm{~cd}$ & $2.9 \mathrm{bc}$ & & & & \\
\hline Selectie Smit & & $0.0 \mathrm{a}$ & $1.5 \mathrm{abcd}$ & $3.3 \mathrm{bcd}$ & $3.1 \mathrm{bcd}$ & & & & \\
\hline Uniflor & & $0.0 \mathrm{ab}$ & $1.3 \mathrm{abc}$ & $2.4 \mathrm{abc}$ & $2.4 \mathrm{~b}$ & & & & \\
\hline Agressor & & & & & & $0.3 \mathrm{ab}$ & $1.8 \mathrm{bc}$ & $1.4 \mathrm{ab}$ & $2.5 \mathrm{bc}$ \\
\hline Ancoma & & & & & & $0.6 \mathrm{bcd}$ & $3.1 \mathrm{defg}$ & $1.2 \mathrm{ab}$ & $3.7 \mathrm{cde}$ \\
\hline Counter & & & & & & $0.6 \mathrm{bcd}$ & 2.8 cdef & $2.7 \mathrm{~cd}$ & $3.3 \mathrm{~cd}$ \\
\hline Selma & & & & & & $0.2 \mathrm{ab}$ & $2.1 \mathrm{bcde}$ & $2.7 \mathrm{~cd}$ & $3.3 \mathrm{~cd}$ \\
\hline WCA 352 & & & & & & $1.5 \mathrm{e}$ & 2.2 bcde & $1.9 \mathrm{bc}$ & $3.3 \mathrm{~cd}$ \\
\hline F1 $($ Bewama $\times$ LB $)$ & & & & & & $0.2 \mathrm{ab}$ & $2.1 \mathrm{bcde}$ & $1.5 \mathrm{ab}$ & $3.4 \mathrm{~cd}$ \\
\hline F1 $($ LB $\times$ Bewama $)$ & & & & & & $0.3 \mathrm{abc}$ & $2.1 \mathrm{bcd}$ & $1.9 \mathrm{bc}$ & $3.1 \mathrm{c}$ \\
\hline
\end{tabular}

Scores are ANOVA means per accession and per harvest over both locations, back-transformed to the original scales. Scores of the same trait followed by the same letter compared within the same harvest are not significantly different $(P=0.05)$

It should be noted that some of the plant traits are correlated in the studied accessions. This is obviously the case for the different traits that are indicative for development of the head. However, among the accessions in our experiments there was also a correlation between leaf surface wax and these development indicators: accessions with early head development tended to have less leaf surface wax than later maturing accessions. 


\section{Discussion}

A clear conclusion from this study is that an early development of the head promotes a larger thrips population and more severe thrips damage later in the season. This follows both from the results of the planting date experiment in 2005 and from the correlation and regressions studies in both years. The earlier maturing accessions in the planting date experiment were less affected by thrips when they were planted later, and therefore were delayed in head development. The regression studies showed that head development in the first two harvests, as measured by development score, firmness, or circumference of the head, is positively correlated with thrips damage in the final harvest. It is interesting that the start of head formation of the earlier accessions coincided with the main peak in the number of the thrips captured on traps in the field in 2006, which occurred in the last week of July (results not shown); Van de Steene et al. (2003) also found peak flight activity of thrips around this period in Belgium in 1998 and 1999. This suggests that the thrips prefer more developed heads on arrival in the field, or that such heads offer better conditions for survival or reproduction. The effect of later planting was also noted by Stoner and Shelton (1988) in a different set of accessions. Thus, the practice of planting early maturing varieties a few weeks later which is being adopted by the organic farming community in the Netherlands will probably reduce the thrips problems in these varieties.

A second conclusion is that thrips damage cannot be predicted accurately based on one specific plant trait, as correlations with individual traits are too low. Rather, we found that Brix and leaf surface wax late in the season and an indicator of developmental stage earlier in the season together are required for predicting thrips damage. In 2005 leaf thickness was also an important factor. A possible role of earliness of head development was already discussed above. The effect of Brix in enhancing thrips damage is probably due to the higher nutritional value of the sap, which may stimulate survival and reproduction of thrips. The effect of leaf surface wax might be to hamper the movement thrips, as has been reported for other small insects in cabbage, probably by wax crystals accumulating on the tarsae (Eigenbrode et al. 1996). To our knowledge no earlier publications report an effect of surface wax on thrips in cabbage. In Gladiolus,
Zeier and Wright (1995) observed that surface wax reduced thrips damage. However, Molenaar (1984) and Bocak (1995) reported that glossy or waxless onions were more susceptible to thrips, and De Oliveira and Castellane (1996) found that leaf wax content was positively correlated with the incidence of thrips in garlic. We see no obvious explanation for the effect of leaf thickness on thrips damage. It is conceivable that the effect of leaf thickness in the fourth harvest of 2005 is a statistical artifact, as it was not observed in 2006 nor in the other harvests of 2005.

The mean number of adult thrips per plant was quite small, even in the most susceptible accessions where considerable damage was observed (Table 3). It is possible that part of the damage was caused by larvae, which feed in the same way as the adults and probably cause the same type of damage. Unfortunately we didn't collect data on the numbers of larvae per plant.

Among the accessions in our study we noted a correlation of late maturity and a large amount of leaf surface wax. This relation appears to hold more generally, as can be seen e.g. from the phenotypic data of the cabbage collection of the Centre of Genetic Resources, The Netherlands at www.cgn.wur.nl. Probably this is a result of the fact that the wax layer offers protection to late-season diseases such as Alternaria leaf spot (Munde and Bhowmik 1985; Conn and Tewari 1989; Singh et al. 1999) which may affect late varieties but are not relevant for early-maturing varieties.

Resistance to thrips appeared to be inherited in an intermediate way in the reciprocal crosses between Bewama (susceptible) and Langendijker Bewaar (resistant). This is not surprising for a trait that is affected by several other traits and therefore probably by several or even many genes. Further progeny of these crosses will be useful to study the joint segregation of thrips resistance and plant traits, allowing to confirm or reject the associations found.

The relations of plant traits with thrips damage reported here may benefit breeders, by offering opportunities for indirect selection for thrips resistance in addition to direct selection based on thrips damage. The traits discussed here will in general be expressed regardless of the severity of thrips infestation, allowing indirect selection for thrips resistance even in seasons with small thrips populations. Conversely, our results may serve as a warning: as resistance to 
thrips is related to traits like earliness, Brix and leaf surface wax, selection for resistance may result in possibly undesired changes in these associated traits.

Acknowledgment This research was funded by the Dutch Ministry of Agriculture, Nature and Food Quality as part of Programme 388-II, Breeding for Organic Farming.

Open Access This article is distributed under the terms of the Creative Commons Attribution Noncommercial License which permits any noncommercial use, distribution, and reproduction in any medium, provided the original author(s) and source are credited.

\section{References}

Bocak L (1995) Comparison of onion cultivars in respect of infestation with onion thrips (Thrips tabaci Lind.). Zahradnictvi 22:11-14 (English abstract)

Conn KL, Tewari JP (1989) Interactions of Alternaria brassicae conidia with leaf epicuticular wax of canola. Mycol Res 93:240-242

De Moel CP, Zwanepol S, Everaarts A, Alblas J, Hoek H (1996) Teelt van sluitkool (Cultivation of cabbage). PAGV, Lelystad, The Netherlands

De Oliveira AP, Castellane PD (1996) Relationship between leaf wax content and thrips population in garlic. Agropec Catarin 9:48-49 (English abstract)

Eigenbrode SD, Castagnola T, Roux MB, Steljes L (1996) Mobility of three generalist predators is greater on cabbage with glossy leaf wax than on cabbage with a wax bloom. Entomol Exp App 81:335-343

Mallows CL (1973) Some comments on Cp. Technometrics 15:661-675

Miller AJ (2002) Subset selection in regression. Monographs on statistics and applied probability 95, 2nd edn. Chapman \& Hall/CRC, p 238
Molenaar ND (1984) Genetics, thrips (Thrips tabaci L.) resistance and epicuticular wax characteristics of nonglossy and glossy onions (Allium cepa L.). Diss Abstr Int B Sci Eng 45:1075B

Munde PN, Bhowmik TP (1985) A source of morphological resistance to leaf blight disease of rape seed and mustard caused by Alternaria brassicae (Berk.) Sacc. Curr Sci India 54:514-515

Payne RW, Murray DA, Harding SA, Baird DB, Soutar DM (2006). GenStat for Windows Introduction, 9th edn. VSN International, Hemel Hempstead, UK

R Development Core Team (2007) R: A language and environment for statistical computing. R Foundation for Statistical Computing, Vienna, Austria. ISBN 3-900051-07-0, URL http://www.R-project.org

Shelton AM, Becker RF, Andaloro JT (1983) Varietal resistance to onion thrips (Thysanoptera: Thripidae) in processing cabbage. J Econ Entomol 76:85-86

Singh DN, Singh NK, Srivastava S (1999) Biochemical and morphological characters in relation to Alternaria blight resistance in rapeseed-mustard. Ann Agr Res 20:72-477

Stoner KA, Dickson MH, Shelton AM (1989) Inheritance of resistance to damage by Thrips tabaci Lindeman (Thysanoptera: Thripidae) in cabbage. Euphytica 40:233-239

Stoner KA, Shelton AM (1986) Studies of resistance to Thrips tabaci in four commercial varieties of cabbage. Cruciferae Newsl 11:101

Stoner KA, Shelton AM (1988) Effect of planting date and timing of growth stages on damage to cabbage by onion thrips (Thysanoptera: Thripidae). J Econ Entomol 81:1186-1189

Van de Steene F, Tirry L, Vidal S (2003) Monitoring the flight activity and damage of Thrips tabaci (Lind) in different varieties of white and red cabbage. Bull OILB-SROP 26:33-37

Zeier P, Wright MG (1995) Thrips resistance in Gladiolus spp.: potential for IPM and breeding. In: Parker BL, Skinner M, Lewis T (eds) Thrips biology and management. Plenum Press, New York, USA 